\title{
Consumer Driven Corporate Environmentalism: Fact or Fiction?
}

\begin{abstract}
Over the last three decades, environmental concerns have moved from being a fringe issue to becoming a major socio-economic issue. While the role of factors such as regulatory and societal pressures, in driving organizations to be environmentally responsive, is now well understood, the role of consumers remains debated. It is however, important to understand the role that consumers play because they can be the crucial pull factor for organizations. This paper re-examines the role of consumers in driving business organizations to be environmentally responsive. Our findings lead us to conclude that, despite the hype surrounding green consumerism, it has not yet matured to the stage where it can influence organizations into being environmentally responsive.
\end{abstract}

Keywords: Environment, Sustainability, Consumer, Developing, Developed, ResourceDependence

\section{Introduction}

Over the last three decades environmental concerns have moved from being a fringe issue to becoming a major socio-economic issue. A growing awareness about the challenges posed by natural environmental constraints, has led governments and societies, in many parts of the world, to coerce business organizations into being environmentally more responsive (Hart, 2007; Welford and Gouldson, 1993). Extant research suggests that an increasing number of businesses are responding to these challenges and are investing in environmentally responsive processes and products (Bendell and Kearins, 2005; Collins et al., in press; Dunphy et al., 2007). While the role of factors such as regulatory and societal pressures, in 
driving organizations to be environmentally responsive, is now well understood (Bansal and Roth, 2000; Hoffman, 2007; Lawrence et al., 2006; Porter and Reinhardt, 2007; Sharma, 2001; Welford, 1998), the role of consumers however, remains debated.

A host of willingness to pay studies suggest that, consumers are willing to pay more for environmentally friendly products (Ottman, 1998; Rowlands, Scott, and Parker, 2003; Shrum et al., 1995). Furthermore, consumer willingness to pay more, for environment friendly products has been shown to hold true across racial (Newell and Green, 1997) and national differences (Bhate, 2002). Additionally, methodological refinements (such as discrete choice analysis - which reportedly better capture consumer preferences), continue to support this contention (Sammer and Wüstenhagen, 2006). This consumer preference is being increasingly manifest in green product development (Albino et al., 2009; Garling and Thogersen, 2001; Gronhoj, 2006; Iles, 2008; Rowlands et al., 2004). This in turn, has led to significant research effort being dedicated to understanding, and developing, profiles of the 'responsible green consumer' (Autio, Heiskanen, and Heinonen, 2009; Fraj and Martinez, 2006).

The existence of powerful green consumers who can strongly influence organizational environmental responsiveness, has thus, become well entrenched both in extant literature and in common parlance (see for e.g. Belz and Schmidt-Riediger, in press; Elkington and Hailes, 1988; Havas Media Reports, 2009; Iyer and Kashyap, 2009; McDonald and Oates, 2006; Moisander and Pesonen, 2002; Paulraj, 2009).

However, the above findings are in stark disagreement with other studies, which find no evidence of consumer driven corporate environmentalism (Peattie, 2001; Peattie and Crane, 
2005; Wong et al., 1996). A very different picture of the green consumer begins to emerge, when the 'willingness to pay' studies, are contrasted with studies, which trace the actual buying behaviour (Manaktola and Jauhari, 2007; Peattie and Crane, 2005; Pedersen and Neergaard, 2006). Researchers are thus increasingly reporting that, despite a significant percentage of consumers indicating a preference for green products (more than 90 percent, according to some opinion poll studies - Havas Media Reports, 2009), consumers however, fail to vote with their money (Grankvist and Biel, 2007).

These studies jointly, paint a picture of Janus faced consumers who - although they professes to be concerned about the environment - displays a marked unwillingness to translate this reported preference into actual buying behaviour. The existence of powerful consumers, who can collectively drive business organizations towards greater environmental responsiveness, is therefore, increasingly being questioned. An emerging body of research suggests that consumers, at least currently, are passive (and even apathetic and uninterested - Prakash, 2002), especially when it comes to translating their reported preferences into actual buying behaviour (Nes and Cramer, 2005; Ozaki, in press; Smallbone, 2004; Steger, 1996; Thomas, 2005). This viewpoint finds further support in research which reports a glaring lack of success in green product categories (Peattie and Crane, 2005; Wong et al., 1996).

The role of consumers in driving organizations to be environmentally responsive thus remains intensely debated. It is however, important to understand the role that consumers play (or can play), because consumers can potentially act as the critical missing link that can take organization from their reactive stances (in response to regulatory compliance or societal pressures), towards proactive responsiveness. Regulatory and societal pressures thus, largely act as the push factors, but if environmentally responsive consumerism is a fact, it would be 
the crucial pull factor for organizations (Dobers and Wolff, 2000). Given this significance of the role of the consumers, we re-examine the role of consumers in driving business organizations to be environmentally responsive.

\section{Definition and theoretical framework}

Drawing from Hart's seminal work (1995), we define corporate environmental responsiveness as integration of natural environmental concerns in both the manufacturing processes, and in product design and development. This definition encompasses both a process and product orientation. The process orientation refers to moving beyond compliance requirements and investing in waste and emission prevention. The product orientation encompasses a product stewardship strategy, wherein organizations include natural environmental challenges, in planning for product design and development.

We draw upon the resource dependence theory (Frooman, 1999; Pfeffer and Salancik, 1978) to provide a theoretical framework for our research. According to the resource dependence theory, business organizations are dependent on the stakeholders (and hence on consumers as external stakeholders) for their resource needs (Pfeffer and Salancik, 1978). It is this dependence of firms on stakeholders for critical resources that gives stakeholders leverage over the firms. Resource dependence thus creates differentials among stakeholders; the more dependent a firm is on a stakeholder for critical resources, the greater is the extent to which that stakeholder can influence the firm's response (Pfeffer and Salancik, 1978).

According to Frooman (1999) resource dependence dynamics (who is dependent on whom), can help in understanding the process by which stakeholders, such as consumers, can gain the required power and become a major influence. Frooman suggests that, one of the most 
powerful strategies available to consumers is the withholding strategy. A withholding strategy is used when stakeholders have absolute discretion over allocation of resources. In such scenarios, the stakeholder can walk out of the relationship with no harm to itself.

Consumers are a particularly good example of stakeholders who have the required power to effectively employ this strategy. As an example, consider the consumer boycotts of Shell in the 1990's (involving the Brent Spar and the Ogoni controversies). The consumer boycotts (consumers withholding their money) led Shell to redefine its mission worldwide to include environmental and human rights concerns (Mirvis, 2000; Shell, 2007; Shell (Nigeria), 2007). The consumer boycott of Nike over sweat shop issues is another relevant example (Anderson, 2005).

In summary, resource dependence theory suggests that in situations where the balance of power lies with the stakeholders, they can withhold resources required by a firm. Consumers therefore - if they so desire - can use their power to withhold buying from any given firm and make it acquiesce to their environmental demands.

\section{Methods}

For research questions seeking to explore "what", "how", or "why" (as opposed to enumerating "how many" or "how much"), qualitative research is the recommended strategy (Creswell, 2003; Eisenhardt, 1989; Eisenhardt and Graebner, 2007; Pratt, 2009; Siggelkow, 2007; Yin, 2003). Since the research question in this paper explores, "what is the role of consumers in driving organizations to be environmentally responsive” - it lends itself to a qualitative exploration. Eisenhardt and Grabener (2007) and Graebner (2009), further suggest that in situations where current theoretical developments provide conflicting accounts, an in- 
depth qualitative enquiry proves to be an especially useful research strategy. Thus because, the role of consumers in driving corporate environmentalism is currently intensely contested, our enquiry seeks to contribute towards theory development through an in-depth multiple case analysis.

The strength of multiple cases lies in their capability to permit replication logic (Eisenhardt and Graebner, 2007; Santos and Eisenhardt, 2009; Yin, 2003). Replication logic allows the cases to be treated as a series of experiments wherein each case serves to confirm or disconfirm the inferences drawn from others. Replication logic thus ensures that the insights gained are not idiosyncratic to a single case but instead are consistently replicated (literally or theoretically) across multiple cases. This leads to more robust theory development (Eisenhardt and Graebner, 2007).

\section{Case selection}

Cases for this research were theoretically sampled from amongst larger organizations (in terms of employee numbers and revenue) both in India and New Zealand. The rationale for focussing on larger organizations is explained by previous research which suggests that only larger organizations tend to exhibit proactive environmental responsiveness that extends beyond compliance (Sharma and Vredenburg, 1998).

We included organizations from India and New Zealand in this study because we sought to examine whether this relationship differed between organizations in developing and developed countries. Research suggests that globalization has ensured the rise of very vocal green consumers in both developing and developed countries (Bhate, 2002). The preferences of these environmentally active consumers are predicted to be very important determinants 
for organizational environmental responsiveness (Havas Media Reports, 2009; Manaktola and Jauhari, 2007). Having organizations from both developing (India) and developed (New Zealand) countries allowed us to explore this contention. The definition of developing and developed countries is based on the United Nations definition of developing and developed countries (United Nations, 2007).

The criterion for further selection of the organizations from amongst the top organizations was an established reputation for environmental responsiveness (based on our earlier definition). Information about measures such as changes in process design to prevent pollution and new green product development were obtained from initial phone calls with corporate communication directors and from content analysis of corporate websites, annual reports, sustainability reports and articles in the media.

To combat social desirability bias (Podsakoff and Organ, 1986), managers who participated in this study were promised confidentiality. This was done in accordance with the procedures suggested by Konrad and Linnehan (1995) who report that securing confidentiality reduces the risk of social desirability bias. Accordingly, to ensure confidentiality, names of the participating organizations have been changed.

\section{Data sources}

Interviews with senior managers - responsible for environmental issues - in 20

environmentally responsive organizations were the primary data source. To ensure reliability, we triangulated the interview data through extensive examinations of the company websites and documents such as annual reports, environmental or sustainability reports, business publications, brochures and copies of public presentations made by the respondents. Where 
possible, we interviewed multiple respondents in an organization. Interviewing multiple respondents provides a closer view of reality (Eisenhardt and Graebner, 2007). 49 interviews were conducted over a period of 21 months from 2005 to 2007. Majority of the interviews were recorded and transcribed verbatim. These transcriptions totalled 614 double spaced pages. When further clarifications were needed, follow-up questions were normally asked through email and phone. The interviews were typically between $60-90$ minutes. The characteristics of the sample firms are summarized in Tables 1 and 2 below.

\begin{tabular}{|c|c|c|c|c|c|}
\hline Organization & Sector & $\begin{array}{c}\text { Revenue } \\
\text { in US \$ } \\
\text { millions } \\
(2006)\end{array}$ & Employees & $\begin{array}{c}\text { Process } \\
\text { improvements }\end{array}$ & $\begin{array}{l}\text { Green product } \\
\text { developments }\end{array}$ \\
\hline Valiance & Petrochemicals & 30,100 & 25,000 & $\sqrt{ }$ & $\sqrt{ }$ \\
\hline Cosmos & Steel & 7,000 & 39,000 & $\sqrt{ }$ & $\sqrt{ }$ \\
\hline ICLL & Pulp and Paper & 3,100 & 21,000 & $\sqrt{ }$ & $\sqrt{ }$ \\
\hline Endeavour & FMCG & 3,000 & 16,000 & $\sqrt{ }$ & $\sqrt{ }$ \\
\hline Sun & Fertilizer & 900 & 100,000 & $\sqrt{ }$ & $\sqrt{ }$ \\
\hline Cottex & Textile & 470 & 4000 & $\sqrt{ }$ & $\sqrt{ }$ \\
\hline Organochem & Chemical & 460 & 4300 & $\sqrt{ }$ & $\sqrt{ }$ \\
\hline Mayer Systems & Electronics & 460 & 4500 & $\sqrt{ }$ & $\sqrt{ }$ \\
\hline
\end{tabular}

Table 1. Profile of case studies in India.

\begin{tabular}{|l|l|l|l|l|c|}
\hline Organization & \multicolumn{1}{|c|}{ Sector } & $\begin{array}{c}\text { Revenue } \\
\text { (in US \$ } \\
\text { millions) } \\
\mathbf{2 0 0 6}\end{array}$ & Employees & $\begin{array}{c}\text { Process } \\
\text { improvements }\end{array}$ & $\begin{array}{c}\text { Green product } \\
\text { developments }\end{array}$ \\
\hline Atlas & Dairy & 10,800 & 16400 & $\sqrt{ }$ & $\sqrt{ }$ \\
\hline Skyes & Construction & 4,300 & 20,000 & $\sqrt{ }$ & $\sqrt{ }$ \\
\hline Shield & Petrochemical & 2100 & 300 & $\sqrt{ }$ & $\sqrt{ }$ \\
\hline Phoenix & $\begin{array}{l}\text { Electricity } \\
\text { Generation }\end{array}$ & 1,545 & 500 & $\sqrt{ }$ & $\sqrt{ }$ \\
\hline Fabio & Food Distribution & 1,540 & 1200 & $\sqrt{ }$ & $\sqrt{ }$ \\
\hline Hercules & Retail Chain & 1,300 & 5500 & $\sqrt{ }$ & $\sqrt{ }$ \\
\hline Amity & Food Industry & 480 & 1500 & $\sqrt{ }$ & $\sqrt{ }$ \\
\hline Solitaire & Mining & 440 & 800 & $\sqrt{ }$ & $\sqrt{ }$ \\
\hline Sunrise & Fertilizer & 360 & 600 & $\sqrt{ }$ & \\
\hline Marion & $\begin{array}{l}\text { Electricity } \\
\text { Distribution }\end{array}$ & 150 & 140 & & $\sqrt{ }$ \\
\hline Waite & $\begin{array}{l}\text { Electronic and } \\
\text { Defence Equipment }\end{array}$ & 150 & 600 & & $\sqrt{ }$ \\
\hline Keratin & Wool Scouring & 100 & 80 & & $\sqrt{ }$ \\
\hline
\end{tabular}

Table 2. Profile of case studies in New Zealand. 


\section{Data analysis}

As is recommended in inductive case study research (Eisenhardt, 1989; Eisenhardt and Graebner, 2007; Miles and Huberman, 1994; Pratt, 2009; Yin, 2003), the first step in data analysis was analysing each case individually. Within case analysis involved developing detailed case histories for each of the organizations. This rich familiarity with each individual case, allowed the unique patterns for each individual case to emerge fully without being influenced and constrained by the patterns of other cases.

Cross case analysis was commenced after the within case analysis had been completed. For cross case analysis, the case study organizations, were examined for similarities and differences. Cross case analysis assisted us in broadening the frame of reference and systematically proceeding beyond initial impressions. The analysis process was iterative and took eight months to complete. The findings and insights obtained from within and cross case analysis, are discussed below.

\section{Findings}

\section{Findings in India}

Our findings reveal that consumers did not influence any of the eight case study organizations in India to be environmentally responsive. We commence our discussion with the case analysis of Endeavour. This case is particularly illustrative of the lack of consumer influence in driving organizations to be environmentally responsive. To the contrary, Endeavour presents a curious paradox, wherein an organization has developed green products but marketplace realities prevent it from positioning the products as environment friendly! Endeavour is amongst the largest FMCG companies in India. It has a consumer base of more than 600 million and annual sales exceeding USD 3 billion. 
Endeavour has successfully developed a detergent which is phosphate free and uses only half the amount of water needed by conventional detergents. Endeavour has also developed a soap bar, which has been made without minerals; NIL MIL Bar. The NIL MIL Bar reduces silting in water, a major environmental problem in India. Despite having developed these products (with clear environmental benefits), lack of consumer demand for environmental attributes had led Endeavour against positioning these products as environment friendly.

This decision, against highlighting the environmental benefits of their green products, was arrived at after extensive market research. Endeavour reports that it "touches the life of two out of three Indians”, and, with more than 6.3 million retail outlets, has an extensive distribution system that extends to even the remotest villages. This massive scale of operations has necessitated a sophisticated consumer research division that engages in extensive and regular consumer research:

We are a three billion dollar company in India and we have got distribution counters in almost every nook of the country. We impact the lives of people right from the time they get up in the morning and sleep in the night - in terms of offering our products which they use. And our research indicates that at least about 60-65 percent of their discretionary income, actually gets spend on Endeavour's products.

\section{We have such a large consumer base and we do regular consumer research, therefore we are able to know what consumers really want.}

This finger on the consumer's pulse led Endeavour to promote its new environment friendly detergent on the basis of convenience offered (have to carry less water) rather than promoting it as a phosphate free environment friendly detergent. It must be mentioned here that the normal practice of washing clothes in India involves manual washing (using water in buckets), as opposed to the western practise of washing clothes using washing machines. 
After extensive consumer research, Endeavour has chosen to promote the new detergent through advertisements which show that instead of having to carry two or more buckets of water (from a distant well or river), the woman of the house has to now carry only one bucket of water. The realties of the Indian marketplace have thus led Endeavour to decide against highlighting the environmentally beneficial attributes of its new detergent. The Director, EHS at Endeavour, stated that consumers currently have a perception that environment friendly goods are of low quality and they will not buy a product on the basis of its environmental attributes. He clearly states that despite Endeavour having developed a green product, they dare not position it as an environment friendly:

We will be wiped out if we start doing that kind (environment friendly) of advertising In India. We have seen it from our experience with competitors.

There are companies like Henko who actually came in wanting to exploit this whole use of non phosphate detergents, they say that our detergent is more eco friendly and things like that, but the fact remains that people still don't see it to be good detergent. Therefore, they are not able to sell it.

If we sell it saying it is environment friendly, the consumer may not want it. In fact they may reject it outright.

If you are not able to sell of course you cannot remain in the business.

So while we are doing it, we will not advertise it in that manner. We won't tell people that this is what we are doing for the environment. That kind of awareness I would say that heightened awareness has not happened in the Indian market as yet.

People still would not buy a product because it is more environmentally friendly.

Findings at ICLL reinforce this. ICLL is a conglomerate and has diversified businesses. It is the only company in India to have developed chlorine free paper. They have also been successful in initiating sustainable forestry programmes. ICLL has also developed eucalyptus clones which yield more pulp, have shorter felling cycles and can be grown in wastelands. Through developing an alternative source of pulp they claim to protect the virgin forests from deforestation. They have further pioneered the replacement of hazardous metal based inks 
with water based inks in printing and have also pioneered a chain of environment friendly hotels. Similar to Endeavour's experience, these environmentally beneficial new products have been developed despite the absence of consumer demand:

Even if we were not environmentally responsible, we could still sell our hotel rooms, so it's not as if we face consumer demand...

Or take our EFC paper. Elemental chlorine free paper. We do not really get a very high premium on that. Nor is there any consumer demand for that.

Cottex is a textile manufacturer and has introduced environment friendly fabrics. It is also engaged in producing environmental friendly dyes. The environmental director however, specifies that none of these measures were a result of consumer demand:

No. There is not a demand from the consumers for the environmentally friendly products. I think consumers in India have got very late and have been left behind in demanding that.

These findings were replicated at Mayer (an electronic manufacturer), which had introduced changes in packaging process that eliminated the use of Methyl Bromide for fumigation. Similarly, Organochem (a chemical manufacturer), had started a process aimed at replacing solvent based adhesive with water based adhesives, without any consumer demand for this. Sun - a fertilizer manufacturer - had introduced a Neem based fertilizer. Neem is a natural derivative and is ecologically less damaging than synthetic fertilizers. There had however been no pressure from the consumers for developing this fertilizer. Cosmos - a steel manufacturer, had introduced steel made of recycled inputs and engaged in industrial ecology, without any consumer demand. Finally, Valiance (a petrochemical business), had innovated fuels with lower emissions. Once again, Valiance did not report any consumer demand or pressures for these innovations. 
A detailed cross case analysis revealed that these product and process innovations, were driven by pressures such as, the necessity to meet supply chain criteria for exporting to developed countries (Cottex, Organochem, Valiance, Mayer, Sun) or by top management commitment and deep-rooted organizational values (Endeavour, ICLL, and Cosmos).

Consumers however were not reported to influence the environmental responsiveness in any of the case study organizations. The responses of the case study organizations in India are summarized in Table 3.

\begin{tabular}{|c|c|c|c|}
\hline Organization & $\begin{array}{l}\text { Product and process } \\
\text { environmental } \\
\text { responsiveness }\end{array}$ & $\begin{array}{l}\text { Role of consumers in } \\
\text { influencing this } \\
\text { orientation }\end{array}$ & $\begin{array}{l}\text { Did consumers } \\
\text { influence } \\
\text { environmental } \\
\text { orientation }\end{array}$ \\
\hline Endeavour (FMCG) & 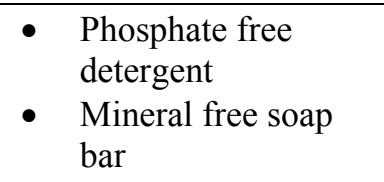 & $\begin{array}{l}\text { Consumers will not buy } \\
\text { a product because it is } \\
\text { more environmentally } \\
\text { friendly. }\end{array}$ & No \\
\hline ICLL (Pulp and Paper) & $\begin{array}{ll}\text { - } & \text { Chlorine free paper } \\
\text { - } & \text { Sustainable forestry } \\
\text { - } & \text { Replacing } \\
& \text { hazardous metal } \\
& \text { based inks with } \\
& \text { water based inks }\end{array}$ & $\begin{array}{l}\text { There is no consumer } \\
\text { demand for that. }\end{array}$ & No \\
\hline Cosmos (Steel) & $\begin{array}{ll}\text { - Industrial ecology } \\
\text { - Recycled steel }\end{array}$ & $\begin{array}{l}\text { Consumers have not } \\
\text { demanded this }\end{array}$ & No \\
\hline $\begin{array}{l}\text { Valiance } \\
\text { (Petrochemical) }\end{array}$ & $\begin{array}{l}\text { - Lower emission } \\
\text { fuels }\end{array}$ & $\begin{array}{l}\text { There was no consumer } \\
\text { demand, when we } \\
\text { started doing it. }\end{array}$ & No \\
\hline Cottex (Textile) & $\begin{array}{ll}- & \text { Environment } \\
\text { friendly dyes } \\
\text { - } & \text { Hemp based } \\
& \text { clothing } \\
\text { - } & \text { Organic cotton } \\
& \text { clothing } \\
\end{array}$ & $\begin{array}{l}\text { No. There is not a } \\
\text { demand from the } \\
\text { consumers for the } \\
\text { environmentally } \\
\text { friendly products. }\end{array}$ & No \\
\hline Sun (Fertilizer) & $\begin{array}{l}\text { Neem (natural, tree } \\
\text { extract) based } \\
\text { ecologically } \\
\text { friendly fertilizer }\end{array}$ & $\begin{array}{l}\text { No, no, nothing from } \\
\text { the farmer's side. }\end{array}$ & No \\
\hline $\begin{array}{l}\text { Organochem } \\
\text { (Chemical) }\end{array}$ & $\begin{array}{l}\text { Water based } \\
\text { adhesives (replacing } \\
\text { harmful solvent } \\
\text { based adhesives) }\end{array}$ & $\begin{array}{l}\text { No demand from } \\
\text { consumers. }\end{array}$ & No \\
\hline Mayer (Electronics) & $\begin{array}{ll}- & \text { Environment } \\
& \text { friendly packaging }\end{array}$ & $\begin{array}{l}\text { No, not from the } \\
\text { consumers. }\end{array}$ & No \\
\hline
\end{tabular}

Table 3. Role of consumers as drivers of environmental orientation in organizations in India. 


\section{Findings in New Zealand}

Our finings in New Zealand closely mirrored the findings obtained from the case study organizations in India. None of the 12 case study organizations in New Zealand credited any aspect of their environmental responsiveness to the final consumer.

Thus the manager at Amity, (a food manufacturer), which has developed biodynamic and organic product lines, explains that consumers are motivated more by price than by the environmental attributes of products:

The motivation for purchasing a product in the supermarket shelf is based on price. If you have a label on your product that says it was produced environmentally sustainably, and your competitor doesn't, but your competitor is significantly cheaper to your price that is a higher motivator for the end consumer.

Hercules, a retail chain business, has in conjunction with Greenpeace, introduced hardwood furniture made from sustainable forestry practices. The furniture is certified as being sustainable and is aimed at alleviating rampant deforestation of rainforests. In attempting to explain the dissonance between the much hyped 'consumer driven environmentalism' and the reality as the manufacturers see it, the manager at Hercules refers to the ambiguity between the willingness to pay and actual buying behaviour:

Consumers say one thing, but do another. There is a gap; there is a dissonance between what consumers say and what they do.

Sunrise - a fertilizer manufacturer, presents a particularly interesting case. Sunrise derives one of the inputs required to make fertilizers from phosphate rocks. Currently, Sunrise imports these phosphate rocks from Western Sahara which has been illegally occupied by Morocco since 1975. The United Nations treats Western Sahara as a disputed issue and New Zealand is only the second country that has been found to have illegally imported phosphates from Western Sahara. Sunrise faces severe opposition and protests from the protest groups 
against the social and environmental consequences of importing phosphate rocks from a forcefully occupied region.

In response to these protest movements Sunrise had invested in manufacturing fertilizers which would use human waste as an input. However, and despite the fact, that this fertilizer was proven to be scientifically safe, Sunrise faced enormous difficulties in getting this human waste based fertilizer accepted by the final consumers. It had to withdraw from this project.

The manager at Sunrise very bluntly dismisses consumer driven corporate environmentalism:

The consumers are hypocrites.

It is hugely hypocritical, it is stunningly hypocritical because they are not thinking of total lifecycles, they are thinking somehow of warm fluffy clean and green but not actually recognising that there's six billion people in the world who have kind of an interface with the environment and closing of the loop makes sense.

This is the irony- by the final market place.

So the final market place likes clean and green, but not if it is a human based or so it becomes quite a selfish market place in some ways. They don't want to, what you may call close the loop and it all puts so many barriers to closing the loop, that a business like ours does wonder what is the worth in doing this?

The responses of the other nine case study organizations in New Zealand reflected very similar experiences and have been summarized in Table 4. Reminiscent of our findings in India, the NZ case study organizations did not view consumers as having any role in influencing their product and process environmental responsiveness. Cross case analysis revealed that NZ case study organizations were largely driven by regulatory and societal (in form of protest groups and environmental NGOs) pressures. 


\begin{tabular}{|c|c|c|c|}
\hline Organization & $\begin{array}{c}\text { Product and process } \\
\text { environmental } \\
\text { responsiveness }\end{array}$ & $\begin{array}{c}\text { Role of consumers in } \\
\text { influencing this } \\
\text { orientation }\end{array}$ & $\begin{array}{c}\text { Did consumer } \\
\text { influence } \\
\text { environmental } \\
\text { Orientation } \\
\end{array}$ \\
\hline Sunrise (Fertilizer) & $\begin{array}{l}\text { Invested in human } \\
\text { waste based fertilizer } \\
\text { ENVIRO: A } \\
\text { revolutionary new } \\
\text { product that prevents } \\
\text { nitrogen leaching }\end{array}$ & $\begin{array}{l}\text { The consumers are } \\
\text { hypocrites. }\end{array}$ & No \\
\hline Skyes (Construction) & $\begin{array}{l}\text { Developed medium } \\
\text { density fibre boards } \\
\text { with extremely low } \\
\text { levels of } \\
\text { formaldehyde. }\end{array}$ & $\begin{array}{l}\text { We do not face any } \\
\text { demand from the end } \\
\text { consumer. }\end{array}$ & No \\
\hline $\begin{array}{l}\text { Amity (Food } \\
\text { industry) }\end{array}$ & $\begin{array}{l}\text { - Organic and } \\
\text { biodynamic foods }\end{array}$ & $\begin{array}{l}\text { The motivation for } \\
\text { purchasing a product in } \\
\text { the supermarket shelf is } \\
\text { based on price. }\end{array}$ & No \\
\hline $\begin{array}{l}\text { Hercules (Retail } \\
\text { chain) }\end{array}$ & $\begin{array}{l}\text { - Sustainable hard wood } \\
\text { furniture }\end{array}$ & $\begin{array}{l}\text { There is a dissonance } \\
\text { between what } \\
\text { consumers say and } \\
\text { what they do }\end{array}$ & No \\
\hline Atlas (Dairy) & $\begin{array}{l}\text { - Reduced packaging } \\
\text { foods } \\
\text { - } \quad \text { LCA }\end{array}$ & $\begin{array}{l}\text { No direct pressure from } \\
\text { consumers. }\end{array}$ & No \\
\hline $\begin{array}{l}\text { Phoenix (Electricity } \\
\text { generation) }\end{array}$ & - Renewable electricity & $\begin{array}{l}\text { Not from end } \\
\text { consumers. }\end{array}$ & No \\
\hline $\begin{array}{l}\text { Fabio (Food } \\
\text { distribution) }\end{array}$ & - $\quad$ Reduced packaging & $\begin{array}{l}\text { No demand from } \\
\text { consumers. }\end{array}$ & No \\
\hline Solitaire (Mining) & $\begin{array}{ll}- & \text { Smokeless pellets } \\
\text { - } & \text { Investing in research } \\
& \text { on low emission coal } \\
\end{array}$ & $\begin{array}{l}\text { No, not from the } \\
\text { consumers as such. }\end{array}$ & No \\
\hline $\begin{array}{l}\text { Marion (Electricity } \\
\text { distribution) }\end{array}$ & $\begin{array}{l}\text { - Producing electricity } \\
\text { from landfill gases }\end{array}$ & No role of consumer & No \\
\hline $\begin{array}{l}\text { Waite (Electronic } \\
\text { and defence } \\
\text { equipment) }\end{array}$ & $\begin{array}{l}\text { Removed lead and } \\
\text { chromium from } \\
\text { electronic products }\end{array}$ & No consumer pressure & No \\
\hline $\begin{array}{l}\text { Keratin (Wool } \\
\text { scouring) }\end{array}$ & - $\quad$ LCA & $\begin{array}{l}\text { Not anything from } \\
\text { consumers }\end{array}$ & No \\
\hline $\begin{array}{l}\text { Shield } \\
\text { (Petrochemical) }\end{array}$ & $\begin{array}{ll}\text { - } & \text { Renewable energy } \\
\text { sources }\end{array}$ & $\begin{array}{l}\text { Nothing from consumer } \\
\text { side. }\end{array}$ & No \\
\hline
\end{tabular}

Table 4. Role of consumers as drivers of environmental orientation in organizations in New Zealand.

\section{Discussion}

As discussed in the introduction, the idea that consumers are powerful and influential drivers of corporate environmentalism is deeply entrenched in extant literature. Our findings 
however find no support for this conception. To the contrary, our findings suggest that consumers are currently uninterested in environmental attributes and are not actively engaged in buying and supporting environment friendly products or processes.

All the 20 case study organizations in our research, distinctly ruled out any consumer demand for product or process environmental responsiveness. Instead, lack of consumer interest and apathy towards environmental attributes had led some of the case study organizations to decide against highlighting the environmental attributes of their products. This intriguing paradox, finds support in research by Thogersen (2006) and Baker and Sinkula (2005), who suggest that lack of consumer demand for environmental attributes, has forced organizations to maintain a low profile for their environmental product range and businesses are increasingly electing against highlighting environmental benefits of their products.

It thus appears that instead of being the much sought after "golden goose", the search for green consumers is indeed proving to be a "wild goose chase" (Peattie, 2001, p. 187). The fact that our findings hold true for business organizations which have been deliberately selected from across a range of industries, and which span both developing and developed countries (which in turn are characterized by political, social, economic, and institutional differences), lends further robustness to our thesis. Based on our findings we propose that:

\section{Proposition: Consumers are currently not driving business organizations to be} environmentally responsive.

To ensure reliability of our thesis, we rigorously examined our findings for alternative explanations. Thus, there is a very real possibility that there exist consumers who are truly green; they however might prefer to adopt the path of voluntary simplicity, reduced consumption or favour non market exchanges (Kozinets, 2002; Kozinets and Handelman, 
2004; Leonard-Barton, 1981; Sen et al., 2001). Additionally, such green minded consumers might exhibit their environment friendly behaviour in non purchase decisions (e.g. recycling), as opposed to explicitly buying green products (Iyer and Kashyap, 2007; Smallbone, 2005; Tilikidou and Delistavrou, 2008). The above discussion suggests that such consumers have not actively chosen to manifest their green preferences to business organizations, and this albeit indirectly - reinforces our thesis.

Furthermore, the complexities of consumer motivation suggest that the purchase of a seemingly green product (e.g. organic food) - may in actuality be motivated purely by health reasons, and environmental concerns have been found to not have featured in the purchase equation (Thompson and Coskuner-Balli, 2007). Research also indicates that environmental concerns may sometimes make an appearance only for products that are aimed at being publicly consumed (e.g. environment friendly car) and the same norms may not be applied to goods aimed at private consumption (Ratner and Kahn, 2002). Finally, research in consumer motivation also suggests that because green products are normally more expensive than conventional products (as they might involve internalizing the externalities) therefore, in the actual buying behaviour of consumers, price considerations, take precedence over environmental attributes (First and Khetriwal, in press; Meyer, 2001).

The above discussion has important implications for our findings. Thus while our findings indicate that currently consumers are not active collaborators in driving businesses to be environmentally responsive, however, a deeper understanding of consumer motivations can still ensure that the elusive green consumer, can perhaps, have a more meaningful and collaborative partnership with businesses in ensuring sustainability. 
Our findings thus (in part) point towards pricing criteria being an important determiner of purchase behaviour. We therefore recommend that the willingness to pay can be cashed upon by matching the product offering with the ability to pay. Environment friendly products do not necessarily have to be expensive, especially when the cost savings that result from process changes are accounted through full costing techniques. Peattie and Crane (2005) further suggest that shifting the emphasis on cost instead of price may be another useful strategy. Thus as an example, solar panels may be viewed more favourably by consumers, if the benefits of reduction in costs over the years of use is highlighted.

For consumers who exhibit their environmentalism through reduced consumption, focussing on environmental processes (rather than products) may be a more effective strategy. The biodynamic food movement has very successfully employed this strategy. Thus while the final product may be tangibly no different from conventional product, highlighting the cleaner processes used in its manufacture, may meet the approval of segment of green consumers. Appropriate labelling can assist with this strategy (Boer, 2003; Prothero et al., 1997)

Finally, while it is true that for the vast majority of consumers, environmental credentials of the product are not a precondition for purchase (Meyer, 2001), opportunities to elicit collaboration, can still be identified. Thus the success of businesses such as Patagonia, suggest that environmental attributes, when stressed subsequent to the product traits desired by consumers (such as performance, price and quality), can be an effective positioning strategy. 
In conclusion, our findings suggest that while consumers currently are not actively influencing organizations towards environmental responsiveness, however, a better understanding of consumer motivations offers considerable scope to ensure a more meaningful and collaborative partnership between businesses and consumers. 


\section{References}

Albino V, Balice A, Dangelico RM. 2009. Environmental strategies and green product development: An overview on sustainability-driven companies. Business Strategy and the Environment 18(2): 83-96.

Anderson DR. 2005. Corporate Survival: The critical importance of sustainability risk management. New York: iUniverse, Inc.

Autio M, Heiskanen E, Heinonen V. 2009. Narratives of green consumers - the antihero, the environmental hero and the anarchist. Journal of Consumer Behaviour 8(1), 40-53.

Baker WE, Sinkula JM. 2005. Environmental marketing strategy and firm performance: Effects on new product performance and market share. Journal of the Academy of Marketing Science 33(4): 461-475.

Bansal P, Roth K. 2000. Why companies go green: A model of ecological responsiveness. Academy of Management Journal 43(4): 717-736.

Belz F-M, Schmidt-Riediger B. in press. Marketing strategies in the age of sustainable development: evidence from the food industry. Business Strategy and the Environment, early view.

Bendell J, Kearins K. 2005. The political bottom line: The emerging dimension to corporate responsibility for sustainable development. Business Strategy and the Environment, 14(6): 372-383.

Bhate S. 2002. One world, one environment, one vision: are we close to achieving this? An exploratory study of consumer environmental behaviour across three countries. Journal of Consumer Behaviour 2(2): 169-184.

Boer JD. 2003. Sustainability labelling schemes: The logic of their claims and their functions for stakeholders. Business Strategy and the Environment, 12(4): 254-264.

Collins E, Roper J, Lawrence S. in press. Sustainability practices: Trends in New Zealand businesses. Business Strategy and the Environment, Early View.

Creswell JW. 2003. Research design, qualitative, quantitative and mixed methods approaches ( 2 ed.). California: Sage Publications.

Dobers P, Wolff R. 2000. Competing with soft issues - from managing the environment to sustainable business strategies. Business Strategy and the Environment 9(3): 143-150.

Dunphy D, Griffiths A, Benn S. 2007. Organizational change for corporate sustainability (2 ed.). London: Routledge.

Eisenhardt KM. 1989. Building theories from case study research. Academy of Management Review 14(4): 532-550.

Eisenhardt KM, Graebner ME. 2007. Theory building from cases: opportunities and challenges. Academy of Management Journal 50(1): 25-32.

Elkington J, Hailes J. 1988. The green consumer guide. London: Gollancz.

First I, Khetriwal DS. in press. Exploring the relationship between environmental orientation and brand value: is there fire or only smoke? Business Strategy and the Environment, Early view.

Fraj E, Martinez E. 2006. Influence of personality on ecological consumer behaviour. Journal of Consumer Behaviour 5(3): 167-181.

Frooman J. 1999. Stakeholder influence strategies. Academy of Management Review 24(2): 191-205.

Garling A, Thogersen J. 2001. Marketing of electric vehicle. Business Strategy and the Environment 10(1): 53-65.

Graebner ME. 2009. Caveat venditor: Trust asymmetries in acquisitions of entrepreneurial firms. Academy of Management Journal 52(3): 435-472. 
Grankvist G, Biel A. 2007. The impact of environmental information on professional purchasers' choice of products. Business Strategy and the Environment 16(6): 421429.

Gronhoj A. 2006. Communication about consumption: A family process perspective on 'green' consumer practices. Journal of Consumer Behaviour 5(6): 491-503.

Hart SL. 1995. A natural resource based view of the firm. Academy of Management Review 20(4): 986-1014.

Hart SL. 2007. Capitalism at the crossroads: aligning business, earth and humanity. New Jersey: Wharton School Publishing.

Havas Media Reports. 2009. This is a staff announcement - could the head of sustainability please come to the check out area. Immediately Retrieved December 2, 2009, from http://www.havasmedialab.com/?p=151

Hoffman AJ. 2007. If you're not at the table you're on the menu. Harvard Business Review 85(10): 34-38.

Iles A. 2008. Shifting to green chemistry: the need for innovations in sustainability marketing. Business Strategy and the Environment 17(8): 524-535.

Iyer ES, Kashyap RK. 2007. Consumer recycling: Role of incentives, information, and social class. Journal of Consumer Behaviour 6(1): 32-47.

Iyer ES, Kashyap RK. 2009. Noneconomic goals of investors. Journal of Consumer Behaviour 8(5): 225-237.

Konrad AM, Linnehan F. 1995. Formalized HRM structures: coordinating equal employment opportunity or concealing organizational practices? Academy of Management Journal 38(3): 787-820.

Kozinets RV. 2002. Can consumers escape the market? Emancipatory illuminations from burning man. Journal of Consumer Research 29(1): 20-38.

Kozinets RV, Handelman JM. 2004. Adversaries of consumption: Consumer movements, activism, and ideology. Journal of Consumer Research 31(3): 691-704.

Lawrence S, Collins E, Pavlovich K, Arunachalam M. 2006. Sustainability practices of SMEs: The case of NZ. Business Strategy and the Environment 15(4): 242-257.

Leonard-Barton D. 1981. Voluntary simplicity lifestyles and energy conservation. Journal of Consumer Research 8(3): 243-252.

Manaktola K, Jauhari V. 2007. Exploring consumer attitude and behaviour towards green practices in the lodging industry in India. International Journal of Contemporary Hospitality Management 19(5): 364-377.

McDonald S, Oates CJ. 2006. Sustainability: Consumer Perceptions and Marketing Strategies. Business Strategy and the Environment 15(3): 157-170.

Meyer A. 2001. What's in it for the customers? Successfully marketing green clothes. Business Strategy and the Environment 10(5): 317-330.

Miles MB, Huberman AM. 1994. Qualitative data analysis: an expanded sourcebook. Thousand Oaks California: Sage Publications.

Mirvis PH. 2000. Transformation at Shell: Commerce and citizenship. Business and Society Review 105(1): 63-84.

Moisander J, Pesonen S. 2002. Narratives of sustainable ways of living: constructing the self and the other as a green consumer. Management Decision 40(4): 329-342.

Nes Nv, Cramer J. 2005. Influencing product lifetime through product design. Business Strategy and the Environment 14(5): 286-299.

Newell SJ, Green CL. 1997. Racial differences in consumer environmental concern. The Journal of Consumer Affairs 31(1): 53-69.

Ottman JA. 1998. Green marketing: Opportunity for innovation. Chicago: NTC business books. 
Ozaki R. in press. Adopting sustainable innovation: What makes consumers sign up to green electricity? Business Strategy and the Environment, Early View.

Paulraj A. 2009. Environmental motivations: a classification scheme and its impact on environmental strategies and practices. Business Strategy and the Environment 18(7): 453-468.

Peattie K. 2001. Golden goose or wild goose? The hunt for the green consumer. Business Strategy and the Environment 10(4): 187-199.

Peattie K, Crane A. 2005. Green marketing: Legend, myth, farce or prophesy? . Qualitative Market Research: An International Journal 8(4): 357-370.

Pedersen ER, Neergaard P. 2006. Caveat emptor - let the buyer beware! environmental labelling and the limitations of green consumerism. Business Strategy and the Environment 15(1): 15-29.

Pfeffer J, Salancik GR. 1978. The external control of organizations. New York: Harper \& Row.

Podsakoff PM, Organ DW. 1986. Self-reports in organizational research: Problems and prospects. Journal of Management 12(4): 531-544.

Porter ME, Reinhardt FL. 2007. A strategic approach to climate. Harvard Business Review 5(10): 22-26.

Prakash A. 2002. Green marketing, public policy and managerial strategies. Business Strategy and the Environment 11(5): 285-297.

Pratt MG. 2009. For the lack of a boilerplate: Tips on writing up (and reviewing) qualitative research. Academy of Management Journal 52(5): 856-861.

Prothero A, Peattie K, McDonagh P. 1997. Communicating greener strategies: A study of onpack communication. Business Strategy and the Environment 6(2): 74-82.

Ratner RK, Kahn BE. 2002. The impact of private versus public consumption on varietyseeking behaviour. Journal of Consumer Research 29(2): 246-257.

Rowlands IH, Parker P, Scott D. 2004. Consumer behaviour in restructured electricity markets. Journal of Consumer Behaviour 3(3): 272-283.

Rowlands IH, Scott D, Parker P. 2003. Consumers and green electricity: profiling potential purchasers. Business Strategy and the Environment 12(1): 36-48.

Sammer K, Wüstenhagen R. 2006. The influence of eco-labelling on consumer behaviour results of a discrete choice analysis for washing machines. Business Strategy and the Environment 15(3): 185-199.

Santos FM, Eisenhardt KM. 2009. Constructing markets and shaping boundaries: Entrepreneurial power in nascent fields. Academy of Management Journal 52(4): 643671.

Sen S, Gürhan-Canli Z, Morwitz VJ. 2001. Withholding consumption: A social dilemma perspective on consumer boycotts. Journal of Consumer Research 28(3): 399-417.

Sharma S. 2001. Different strokes: regulatory styles and environmental strategy in the North American oil and gas industry. Business Strategy and the Environment 10(6): 344364.

Sharma S, Vredenburg H. 1998. Proactive corporate environmental strategy and the development of competitively valuable organizational capabilities. Strategic Management Journal 19(8): 729-753.

Shell. 2007. Brent Spar. Retrieved June 7 2007, from http://www.shell.com/home/Framework?siteId=uk-en\&FC2=/uken/html/iwgen/about_shell/brentspardossier/brentsparstory/zzz_lhn.html\&FC3=/uken/html/iwgen/about_shell/brentspardossier/brentsparstory/thestory_09101000.html

Shell (Nigeria). 2007. The Ogoni issue. Retrieved June 7 2007, from http://www.shell.com/home/content/nigeria/about_shell/issues/ogoni/ogoni.html 
Shrum LJ, McCarty JA, Lowrey TM. 1995. Buyer characteristics of the green consumer and their implications for advertising strategy. Journal of Advertising 24(2): 71-82.

Siggelkow N. 2007. Persuasion with case studies. Academy of Management Journal 50(1): 20-24.

Smallbone T. 2004. Can market transformation lead to sustainable business? A critical appraisal of the UK's strategy for sustainable business. Business Strategy and the Environment 13(2): 96-106.

Smallbone T. 2005. How can domestic households become part of the solution to England's recycling problems? Business Strategy and the Environment 14(2): 110-122.

Steger U. 1996. Managerial issues in closing the loop. Business Strategy and the Environment 5(4): 252-268.

Thogersen J. 2006. Media attention and the market for green consumer products. Business Strategy and the Environment 15(3): 145-156.

Thomas TE. 2005. Are business students buying it? A theoretical framework for measuring attitudes toward the legitimacy of environmental sustainability. Business Strategy and the Environment 14: 186-197.

Thompson CJ, Coskuner-Balli G. 2007. Countervailing market responses to corporate cooptation and the ideological recruitment of consumption communities. Journal of Consumer Research 34(2): 135-152.

Tilikidou I, Delistavrou A. 2008. Types and influential factors of consumers' non-purchasing ecological behaviors. Business Strategy and the Environment 17(1): 61-76.

United Nations. 2007. United Nations Common Database. Retrieved June 27, 2007, from http://unstats.un.org/unsd/cdb/cdb_dict_xrxx.asp?def_code $=491$

Welford RJ. 1998. Editorial: Corporate environmental management, technology and sustainable development: postmodern perspectives and the need for a critical research agenda. Business Strategy and the Environment, 7(1): 1-12.

Welford RJ, Gouldson A. 1993. Environmental management and business strategy. London: Pitman Pub.

Wong V, Turner W, Stoneman P. 1996. Marketing strategies and market prospects for environmentally- friendly consumer products. British Academy of Management 7(3): 263-281.

Yin RK. 2003. Case study research: Designs and methods (3 ed.). Thousand Oaks, California: Sage Publications. 